\title{
Predictors of clinical outcomes after cardiac resynchronization therapy in patients $\geq 75$ years of age: a retrospective cohort study
}

Laure Champ-Rigot ${ }^{*}$ (D), Anne-Laure Cornille ${ }^{2}$, Pierre Ollitrault ${ }^{2}$, Arnaud Pellissier ${ }^{2}$, Mathieu Chequel ${ }^{2}$, Damien Legallois ${ }^{1}$ and Paul Milliez ${ }^{1}$

\begin{abstract}
Background: Cardiac resynchronization therapy has been shown to benefit selected patients with heart failure and reduced ejection fraction. Older patients have been underrepresented in randomized trials. This study was conducted to determine whether predictive factors for cardiac resynchronization therapy outcomes differ in patients older and younger than 75 years of age.

Methods: Consecutive patients who received a cardiac resynchronization device cardiac resynchronization therapy between 2013 and 2016 in our center were retrospectively included in this cohort study. The primary endpoint was cardiac resynchronization therapy effectiveness, which was defined as survival for one year with both no heart failure hospitalization and improvement by one or more NYHA class. The secondary endpoints were mortality, complications, and device therapies.

Results: Among the 243 patients included, 102 were $\geq 75$ years old. Cardiac resynchronization therapy effectiveness was observed in 70 patients $(50 \%)<75$ years old and in 48 patients $(47 \%) \geq 75$ years old $(p=0.69)$. NYHA class $\geq$ III $(\mathrm{OR}=6.02 ; \mathrm{Cl} 95 \%$ [1.33-18.77], $p=0.002)$ was a predictive factor for cardiac resynchronization therapy effectiveness only in the $\geq 75$-year-old group, while atrial fibrillation was independently negatively associated with the primary endpoint in the $<75$-year-old group ( $\mathrm{OR}=0.28$; Cl95\% [0.13-0.62], $p=0.001)$. The one-year mortality rate was $14 \%$, with no difference between age groups. Rescue cardiac resynchronization therapy and atrial fibrillation were independent predictive factors for mortality in both age groups. Eighty-two complications occurred in 45 patients (19\%), with no difference between groups. Defibrillator use and QRS duration were independent predictive factors for complications in both age groups. There was no difference between groups considering device therapies.

Conclusion: At one year, cardiac resynchronization therapy response is not compromised by patient age. In older patients, highly symptomatic individuals with NYHA class $\geq 1$ II have better outcomes after cardiac resynchronization therapy.
\end{abstract}

Keywords: Resynchronization therapy, Heart failure, Aged, Treatment outcome

\footnotetext{
* Correspondence: champrigot-l@chu-caen.fr

${ }^{1}$ Normandie University, UNICAEN, CHU de Caen Normandie, Service de

Cardiologie, EA4650 (Signalisation, électrophysiologie et imagerie des lésions

d'ischémie-reperfusion myocardique), 14000 Caen, France

Full list of author information is available at the end of the article
}

(c) The Author(s). 2019 Open Access This article is distributed under the terms of the Creative Commons Attribution 4.0 International License (http://creativecommons.org/licenses/by/4.0/), which permits unrestricted use, distribution, and reproduction in any medium, provided you give appropriate credit to the original author(s) and the source, provide a link to the Creative Commons license, and indicate if changes were made. The Creative Commons Public Domain Dedication waiver (http://creativecommons.org/publicdomain/zero/1.0/) applies to the data made available in this article, unless otherwise stated. 


\section{Background}

Cardiac resynchronization therapy (CRT) has become a standard therapy for patients with chronic heart failure (HF) related to reduced left ventricular ejection fraction (LVEF). Large clinical trials have demonstrated CRT benefits on symptoms, quality of life, as well as morbidity and mortality reduction [1-4]. The current guidelines recommend CRT for selected patients regardless of age status [5], but older patients, defined as individuals aged $\geq 65$, especially those aged $\geq 75$, have been underrepresented in these studies [6]. The prevalence of HF increases with age, and the European Survey on CRT reported that the median age of patients with $\mathrm{HF}$ was 70 , with $31 \%$ of the patients being aged $\geq 75$ [7] . A few reports have previously highlighted the feasibility and efficiency of CRT in older patients, but little is known about the predictors of clinical responses in this population [8-12].

We aimed to determine age-related predictive factors for clinical outcomes in older patients receiving CRT.

\section{Methods}

We designed a retrospective cohort study according to the guidelines for reporting observational studies and fulfilling the STROBE statement items, detailed in Additional file 1 [13].

\section{Study population}

We retrospectively included all consecutive patients referred to Caen Normandy University Hospital for CRT device implantation between January 2013 and December 2016. CRT devices were implanted according to the most recent European guidelines [14]: New York Heart Association (NYHA) functional class II to ambulatory IV, LVEF $\leq 35 \%$, QRS duration $\geq 120 \mathrm{~ms}$ and left-bundle branch block (LBBB) QRS morphology or QRS duration $\geq 150 \mathrm{~ms}$ and non-LBBB QRS morphology, despite optimized medical treatment. After publication of the latest guidelines in 2016 [5], the minimum QRS duration required was $130 \mathrm{~ms}$ in cases of LBBB QRS morphology. Patients with a ventricular pacing indication and reduced LVEF as well as those who had a previous device upgraded to a CRT pacemaker or CRT defibrillator were also included. We also considered patients who underwent implantation for rescue CRT, which is defined as the implantation of a CRT device for amine-dependent end-stage HF. We excluded patients under 18 years of age and those who were lost to follow-up. We defined older patients as those who were $\geq 75$ years old at the time of implantation and then divided our population into two age groups: individuals aged $<75$ and individuals aged $\geq 75$.

\section{Device therapy}

The CRT device was implanted using standard techniques. In patients with atrial fibrillation (AF), atrioventricular node ablation was performed when medical treatment failed to control their heart rate. The choice between a defibrillator and pacemaker for the primary prevention of sudden cardiac death, as well as baseline programming, was at the discretion of the attending physician.

\section{Data collection}

Evaluation of the candidates for CRT implantation, except those undergoing rescue-CRT, had to be performed in our center within three months before the procedure, and included a 12-lead electrocardiogram and a standard two-dimensional echocardiogram performed with the IE $33^{\mathrm{TM}}$ or Epic $5^{\mathrm{TM}}$ system (Philips Healthcare, Amsterdam, Netherlands) with the measurement of LVEF using Simpson's biplane method. Clinical, biological, electrocardiogram and echocardiographic data were anonymously collected.

\section{Follow-up and clinical endpoints}

Patients' follow-ups were scheduled according to our standard of care with a physical examination and device interrogation before hospital discharge, at one month, at six months and at one year. A remote monitoring system was proposed if appropriate.

The primary endpoint was CRT effectiveness, defined as a modified combined clinical score, which has been previously described as follows [9]: survival for one year with no heart failure hospitalization and improvement by $\geq$ one NYHA class. The secondary endpoints were all-cause mortality, complications, and the occurrence of device therapies in patients with a defibrillator. Appropriate device therapy was defined as anti-tachycardia pacing and/or internal shocks delivered to terminate sustained ventricular arrhythmia. Device therapy delivered in any other circumstance was considered inappropriate.

\section{Statistical analysis}

Categorical variables were expressed as numbers and percentages and compared using Pearson's chi-squared test or Fisher's exact test depending on whether the data met the criteria for a given test. Continuous variables were expressed as the mean and standard deviation if the data were normally distributed or the median and interquartile range if the data were not normally distributed. The data were then compared using Student's t-test or the Mann-Whitney U test. The association between the baseline characteristics and the occurrence of clinical events was evaluated by univariate analysis. Variables with $p$ values $\leq 0.20$ in univariate analysis were then introduced in multivariate analysis using a binary logistic regression model with Wald's step-by-step 
method. The survival time for the primary endpoint was defined as the number of days between implantation and the first event. The Kaplan-Meier method was used to construct survival curves, and the log-rank test used to conduct comparisons among groups. Statistical significance was set at a two-tailed probability level of $<0.05$. All analyses were performed using IBM SPSS Statistics for Windows version 20.0 (IBM Corp. Released 2011. Armonk, NY: IBM Corp.).

\section{Results}

\section{Baseline characteristics}

Two hundred fifty patients underwent CRT implantation; among them, 7 were excluded because of missing follow-up data. Hence, our study population comprised the remaining 243 patients, of which 102 (42\%) were $\geq$ 75 years old. The baseline characteristics according to the age groups are summarized in Table 1 . The patients were predominantly male, but there were more females in the $\geq 75$-year-old group (23\%) than in the $<75$-yearold group (13\%) $(p=0.04)$. A larger proportion of the patients $\geq 75$ years old compared with those $\geq 75$ years old had severe symptoms according to the NYHA class, had chronic kidney disease (CKD, defined by estimated glomerular filtration $<60 \mathrm{ml} / \mathrm{min} / 1.73 \mathrm{~m}^{2}$ ), and were receiving loop diuretics, but fewer patients in this group were receiving aldosterone antagonists. However, patients $\geq 75$ years old were less likely to have defibrillator than those $<75$ years old ( $52 \%$ versus $87 \%$, respectively; $p<0.001)$. Both groups had a comparable level of LVEF impairment, with a median LVEF of $28 \%$ (23.5-30), and mostly a LBBB QRS morphology (79\%). There was no difference regarding the proportion of upgraded devices, CRT for rescue therapy and time of the procedure.

\section{Primary endpoint}

There was no difference in CRT effectiveness between age groups; 70 patients were considered responders out of the 141 (50\%) in the < 75-year-old group, whereas 48 patients out of the 102 (47\%) in the $\geq 75$-year-old group were considered responders $(p=0.69)$. The outcomes are detailed in Table 1. In univariate and multivariate analyses, NYHA class $\geq$ III before implantation was associated with the CRT response in the overall population ( $\mathrm{OR}=3.30$; $95 \%$ confidence interval (CI95\%) [1.70-6.51], $p<0.001)$. NYHA class $\geq$ III was strongly predictive of CRT effectiveness among older patients (OR =6.02; CI95\% [1.33-18.77], $p=0.002)$. In the $<75$-year-old group, there was a trend towards a better CRT response in patients with a previous NYHA class $\geq$ III $(p=0.07)$. In univariate analysis, AF, CKD and rescue CRT were negatively associated with the CRT response. Only AF and CKD remained predictors of CRT nonresponse in the multivariate analysis of the overall population. Moreover, the AF negative impact was significant only in the $<75$ year-old group ( $\mathrm{OR}=0.28$; C195\% [0.13-0.62], $p=0.001$ ) and was not significant in the $\geq 75$-year-old group. Defibrillator use was not associated with the primary endpoint. The results of the univariate and multivariate analyses in the $\geq 75$-year-old group are listed in Table 2 and those in the < 75-year-old group are provided in Table 3.

\section{Secondary endpoints \\ All-cause mortality}

At one year, the mortality rates were 12 and $17 \%$ in the $<75$ - and $\geq 75$-year-old groups, respectively $(p=0.31)$. The survival curves are represented in Fig. 1. Defibrillator use was associated with better survival in the univariate analysis $(p=0.01)$ but not after the logistic regression. The multivariate analysis showed that rescue CRT ( $p=0.01$ and 0.002 in the $\geq 75$ - and $<75$-year-old groups, respectively) and AF ( $p=0.04$ and 0.02 in the $\geq 75$ - and $<75$-year-old groups, respectively) were associated with mortality in both groups. CKD was predictive of one-year mortality only in the $<75$-year-old group $(p=0.04)$, whereas ivabradine use was associated with mortality only in the $\geq 75$-year-old group $(p=0.04)$.

\section{Complications}

Eighty-two complications were reported in $45 \mathrm{pa}$ tients (19\%) in the study population. There was no difference in the one-year complication rates between age groups, which were 15 and $21 \%$ in the $\geq 75$ - and $<75$-year-old groups, respectively $(p=0.19)$. Lead dislodgment and reinterventions were the most frequent issues, with a trend towards a greater rate of reinterventions in the $<75$-year-old group ( $p=$ $0.07)$. Only defibrillator use $(p=0.003)$ and QRS duration $(p=0.02)$ were found to be independent predictive factors in the overall population. There was no age-related predictor of complications.

\section{Device therapies in patients with a defibrillator $(n=175)$}

Nine (17\%) patients $\geq 75$ years old received appropriate therapies, whereas 11 (9\%) patients < 75 years old received appropriate therapies $(p=0.2)$. Only four patients, who were all in the $<75$-year-old group, received inappropriate therapies.

\section{Discussion}

In our study, older patients who underwent CRT presented more comorbidities than did their younger counterparts. Such differences have been highlighted in other studies [8] and registries [7, 15]. However, they tended to have a response to CRT similar to that of younger individuals, considering a clinical combined endpoint for CRT effectiveness defined as survival for one year with no heart failure hospitalization and improvement by $\geq$ one NYHA class. Patients $\geq 75$ years old with a previous diagnosis of a NYHA class $\geq$ III were found to respond 
Table 1 Baseline characteristics and outcomes

\begin{tabular}{|c|c|c|c|}
\hline & $<75$ years old $(n=141)$ & $\geq 75$ years old $(n=102)$ & $p$ value \\
\hline Age (years) & $64(10)$ & $79(7)$ & $<0.001$ \\
\hline Male sex, n (\%) & $122(87)$ & $78(77)$ & 0.04 \\
\hline Ischemic cardiomyopathy, n (\%) & $71(50)$ & $63(62)$ & 0.08 \\
\hline Atrial fibrillation, n (\%) & $66(47)$ & $56(57)$ & 0.14 \\
\hline Diabetes mellitus, n (\%) & $44(31)$ & $29(29)$ & 0.71 \\
\hline CKD, n (\%) & $62(49)$ & $68(72)$ & 0.001 \\
\hline \multicolumn{4}{|l|}{ NYHA functional class, n (\%) } \\
\hline । & $3(2)$ & $1(1)$ & \multirow[t]{5}{*}{0.01} \\
\hline$\|$ & $57(40)$ & $22(21)$ & \\
\hline III & $52(37)$ & $62(61)$ & \\
\hline IV ambulatory & $7(5)$ & $7(7)$ & \\
\hline IV in hospital & $22(16)$ & $10(10)$ & \\
\hline Rescue CRT, n (\%) & $14(10)$ & $8(8)$ & 0.58 \\
\hline Beta blocker, n (\%) & $119(85)$ & $78(79)$ & 0.21 \\
\hline ACEI or ARB, $n(\%)$ & $112(80)$ & $71(72)$ & 0.14 \\
\hline Aldosterone antagonist, n (\%) & $71(51)$ & $36(36)$ & 0.03 \\
\hline Loop diuretic, n (\%) & $105(75)$ & $85(86)$ & 0.04 \\
\hline Ivabradine, n (\%) & $21(15)$ & $11(11)$ & 0.38 \\
\hline Anticoagulation therapy, n (\%) & $73(52)$ & $59(58)$ & 0.33 \\
\hline Anti-platelet agent, n (\%) & $73(52)$ & $55(54)$ & 0.60 \\
\hline \multicolumn{4}{|l|}{ QRS morphology, n (\%) } \\
\hline LBBB & $110(78)$ & $82(80)$ & \multirow[t]{4}{*}{0.50} \\
\hline RBBB & $10(7)$ & $6(6)$ & \\
\hline NIVCD & $3(2)$ & 0 & \\
\hline Paced QRS & $18(13)$ & $14(14)$ & \\
\hline LVEF (\%) & $28(6)$ & $28(7)$ & 0.47 \\
\hline CRT-D, n (\%) & $122(87)$ & $53(52)$ & $<0,001$ \\
\hline Upgrade, n (\%) & $41(29)$ & $25(25)$ & 0.43 \\
\hline Effectiveness, n (\%) & $70(50)$ & $48(47)$ & 0.69 \\
\hline One-year survival & $124(88)$ & $85(83)$ & 0.31 \\
\hline NYHA improvement & $86(61)$ & $67(66)$ & 0.72 \\
\hline No admission for HF & $107(76)$ & $71(70)$ & 0.33 \\
\hline Complications, $\mathrm{n}$ in n patients (\%) & 55 in $30(21)$ & 27 in $15(15)$ & 0.19 \\
\hline Reintervention, n (\% of complications) & $24(44)$ & $9(33)$ & 0.07 \\
\hline Lead displacement, n (\% of complications) & $19(34)$ & $7(26)$ & 0.10 \\
\hline Implantation failure, $\mathrm{n}$ (\% of complications) & $3(5)$ & $5(19)$ & 0.23 \\
\hline Infection, n (\% of complications) & $6(11)$ & $3(11)$ & 0.59 \\
\hline Pneumothorax, n (\% of complications) & $2(4)$ & $2(7)$ & 0.74 \\
\hline Perforating lead, $n$ (\% of complications) & 0 & $1(4)$ & 0.24 \\
\hline Pericardial effusion, n (\% of complications) & $1(2)$ & 0 & 0.39 \\
\hline Hematoma, n (\% of complications) & 0 & 0 & NA \\
\hline
\end{tabular}

Continuous variables are reported as medians and interquartile ranges; categorical variables are reported as numbers and percentages. ACEl: angiotensinconverting enzyme inhibitor; ARB: angiotensin II receptor blocker; CKD: chronic kidney disease (defined by estimated glomerular filtration $<60 \mathrm{ml} / \mathrm{mn} / 1.73 \mathrm{~m}{ }^{2}$ ); CRT: cardiac resynchronization therapy; CRT-D: CRT with defibrillator; HF: heart failure; LBBB: left bundle branch block; LVEF: left ventricular ejection fraction; NYHA: New York Heart Association; NIVCD: nonspecific intraventricular conduction delay; RBBB: right bundle branch block 
Table 2 Univariate and multivariate analyses of outcomes in the $\geq 75$-year-old group

\begin{tabular}{|c|c|c|c|c|c|c|}
\hline & \multicolumn{2}{|l|}{ Univariate analysis } & \multicolumn{2}{|c|}{$\begin{array}{l}\text { Multivariate analysis } \\
\text { (model } 1 \text { with atrial fibrillation) }\end{array}$} & \multicolumn{2}{|c|}{$\begin{array}{l}\text { Multivariate analysis } \\
\text { (model } 2 \text { with anticoagulation) }\end{array}$} \\
\hline & OR $(95 \% \mathrm{Cl})$ & $p$ value & $\mathrm{OR}(95 \% \mathrm{Cl})$ & $p$ value & $\mathrm{OR}(95 \% \mathrm{Cl})$ & $p$ value \\
\hline \multicolumn{7}{|l|}{ Primary endpoint } \\
\hline $\mathrm{NYHA} \geq \mathrm{III}$ & $5.91(2.02-17.30)$ & 0.001 & $6.02(1.33-18.77)$ & 0.002 & $6.30(2.04-19.67)$ & 0.001 \\
\hline Rescue CRT & $0.49(0.40-0.60)$ & 0.01 & & & & \\
\hline CKD & $0.41(0.16-1.03)$ & 0.06 & & & & \\
\hline Loop diuretics & $0.32(0.09-1.11)$ & 0.06 & & & & \\
\hline Anticoagulation & $0.51(0.23-1.15)$ & 0.10 & & & & \\
\hline Atrial fibrillation & $0.51(0.23-1.15)$ & 0.10 & & & & \\
\hline ACEI-ARB & $2.07(0.84-5.11)$ & 0.11 & $2.55(0.91-7.11))$ & 0.07 & $2.38(0.87-6.49)$ & 0.09 \\
\hline Surgery duration & $1.87(0.85-4.11)$ & 0.12 & & & & \\
\hline $\mathrm{QRS}=130-150 \mathrm{~ms}$ & $0.50(0.20-1.27)$ & 0.14 & & & & \\
\hline \multicolumn{7}{|l|}{ One-year mortality } \\
\hline Rescue CRT & $58.8(6.55-528-28)$ & $<0.001$ & $44.67(2.91-686)$ & 0.01 & $63.28(4.47-896)$ & 0.002 \\
\hline CRT-D & $0.23(0.07-0.75)$ & 0.01 & & & & \\
\hline Atrial fibrillation & $4.03(1.07-15.20)$ & 0.03 & $6.72(0.99-45.61)$ & 0.04 & & \\
\hline QRS $>150 \mathrm{~ms}$ & $2.64(0.86-8.15)$ & 0.08 & $3.79(0.79-18.21)$ & 0.10 & & \\
\hline Surgery duration & $0.39(0.13-1.2)$ & 0.09 & $0.11(0.02-0.63)$ & 0.01 & $0.14(0.03-0.76)$ & 0.02 \\
\hline CKD & $3.54(0.75-16.67)$ & 0.09 & & & & \\
\hline Upgrade & $0.36(0.08-1.69)$ & 0.10 & & & & \\
\hline Anticoagulation & $2.43(0.72-8.13)$ & 0.14 & & & & \\
\hline Beta-blockers & $0.42(0.12-1.42)$ & 0.15 & & & & \\
\hline Ivabradine & $2.63(0.60-11.41)$ & 0.18 & $9.99(1.17-85.42)$ & 0.04 & $6.36(1.10-36.90)$ & 0.04 \\
\hline ACEI-ARB & $0.47(0.15-1.49)$ & 0.19 & & & & \\
\hline
\end{tabular}

Anticoagulation and atrial fibrillation were significantly correlated in the $\geq 75$-year-old group (Pearson coefficient $0.79, p<0.001$ ). We performed two different regression models if the $p$ values were both $<0.2$ in the univariate analysis. We reported here variables with $p$ values $\leq 0.2$ in the univariate analysis and $\leq 0.10$ in the multivariate analysis. ACEI: angiotensin-converting enzyme inhibitor; ARB: angiotensin II receptor blocker; CKD: chronic kidney disease (defined by estimated glomerular filtration $<60 \mathrm{ml} / \mathrm{mn} / 1.73 \mathrm{~m}^{2}$ ); CRT: cardiac resynchronization therapy; CRT-D: CRT with defibrillator; NYHA: New York Heart Association

better than less symptomatic individuals, whereas functional status was not predictive factor for CRT response in younger individuals. CRT was also found to be safe in both age groups, with no difference in the mortality rate or in the complication rate. The strongest predictors of mortality, rescue CRT and AF, were not age-related.

Whether CRT can be as efficient in older patients as it is in younger patients remains unknown. Observational studies have shown that older patients are likely to respond to CRT as well as younger patients are $[8,9,16,17]$. In our study, age was not predictive factor for CRT response, as a subanalysis of two randomized trials comparing three age groups $(<65$; $65-75$; > 75 years) reported the same improvements in LVEF and NYHA class regardless of age [18]. In contrast, Maass et al. recently identified age $<60$ years as a predictive factor for reverse ventricular remodeling after CRT [19]. Little is known about response predictors according to age. We reported here for the first time that NYHA class $\geq \mathrm{III}$ at the time of implantation was associated with CRT response in the 275 -year-old individuals but not in younger patients. Conversely, a recent study showed that NYHA class $\leq$ III was an independent predictor of CRT benefit in a mid-sixties population [20]. In contrast, AF has been associated with poor results of CRT [21]. In our study, this negative impact of AF was found in the younger group, whereas patients $\geq 75$ years with AF improved as well as those in sinus rhythm did.

There are conflicting results regarding the impact of CRT on mortality among older patients. We found no difference in mortality rates between age groups. This result was also reported in previous studies $[9,10]$. Killu et al. showed, after performing a multivariate analysis, that there was no significant difference in survival between patients aged $\leq 80$ and > 80 [10]. In contrast, several authors noted higher mortality rates among older patients $[11,15,17,22]$ but more noncardiac deaths in these patients [22] and a similar time to death between age groups [11]. Diabetes mellitus, CKD and low functional capacity were predictive of worse survival in 
Table 3 Univariate and multivariate analyses of outcomes in the $<75$-year-old group

\begin{tabular}{|c|c|c|c|c|c|c|}
\hline & \multicolumn{2}{|l|}{ Univariate analysis } & \multicolumn{4}{|l|}{ Multivariate analysis } \\
\hline Primary endpoint & OR (95\% Cl) & $p$ value & \multicolumn{2}{|l|}{ OR (95\% Cl) } & \multicolumn{2}{|l|}{$p$ value } \\
\hline Atrial fibrillation & $0.36(0.18-0.71)$ & 0.003 & \multicolumn{2}{|l|}{$0.28(0.13-0.62)$} & \multicolumn{2}{|l|}{0.001} \\
\hline CRT-D & $2.39(0.85-6.70)$ & 0.09 & & & & \\
\hline Male sex & $2.39(0.85-6.70)$ & 0.09 & & & & \\
\hline CKD & $0.53(0.26-1.07)$ & 0.08 & & & & \\
\hline Ivabradine & $2.25(0.85-5.97)$ & 0.10 & & & & \\
\hline$N Y H A \geq I I I$ & $1.74(0.89-3.41)$ & 0.11 & $2.09(0.95-4.59)$ & & 0.07 & \\
\hline QRS $<130 \mathrm{~ms}$ & $0.51(0.21-1.24)$ & 0.13 & & & & \\
\hline \multirow[t]{2}{*}{ QRS $>150 \mathrm{~ms}$} & $1.63(0.83-3.17)$ & 0.15 & & & & \\
\hline & \multicolumn{2}{|l|}{ Univariate analysis } & \multicolumn{2}{|c|}{$\begin{array}{l}\text { Multivariate analysis } \\
\text { (model } 1 \text { with atrial fibrillation) }\end{array}$} & \multicolumn{2}{|c|}{$\begin{array}{l}\text { Multivariate analysis } \\
\text { (model } 2 \text { with anticoagulation) }\end{array}$} \\
\hline One-year mortality & OR (95\% Cl) & $p$ value & OR $(95 \% \mathrm{Cl})$ & $p$ value & OR $(95 \% \mathrm{Cl})$ & $p$ value \\
\hline Atrial fibrillation & 23.68 (3.04-184.30) & $<0.001$ & $14.35(1.6-125.90)$ & 0.02 & & \\
\hline Rescue CRT & $17.48(4.97-61.44)$ & $<0.001$ & $14.32(2.61-79.20)$ & 0.002 & $15.81(3.35-75.10)$ & $<0.001$ \\
\hline CRT-D & $0.11(0.04-0.34)$ & $<0.001$ & & & & \\
\hline Beta-blockers & $0.16(0.05-0.51)$ & 0.001 & & & & \\
\hline CKD & $5.93(1.61-21.83)$ & 0.003 & $5.96(1.13-31.30)$ & 0.04 & $7.65(1.47-39.61)$ & 0.02 \\
\hline Anticoagulation & $7.71(1.68-33.26)$ & 0.003 & & & $5.32(0.96-29.40)$ & 0.06 \\
\hline ACEI-ARB & $0.26(0.09-0.78)$ & 0.01 & & & & \\
\hline Diabetes mellitus & $2.86(1.02-8.01)$ & 0.04 & & & & \\
\hline Loop diuretics & $5.67(0.72-44.56)$ & 0.07 & & & & \\
\hline$N Y H A \geq I I I$ & $4.24(1.16-15-48)$ & 0.02 & & & & \\
\hline QRS $>150 \mathrm{~ms}$ & $0.46(0.15-1.38)$ & 0.16 & & & & \\
\hline Complications & $2.06(0.69-6.08)$ & 0.19 & $4.20(0.91-18.91)$ & 0.07 & & \\
\hline
\end{tabular}

Anticoagulation and atrial fibrillation were significantly correlated in the $<75$-year-old group (Pearson coefficient $0.69, p<0.001$ ). We performed two different regression models if the $p$ values were both $<0.2$ in the univariate analysis. We reported here variables with $p$ values $\leq 0.2$ in the univariate analysis and $\leq 0.10$ in the multivariate analysis. ACEl: angiotensin-converting enzyme inhibitor; ARB: angiotensin II receptor blocker; CKD: chronic kidney disease (defined by estimated glomerular filtration $<60 \mathrm{ml} / \mathrm{mn} / 1.73 \mathrm{~m}^{2}$ ); CRT: cardiac resynchronization therapy; CRT-D: CRT with defibrillator; NYHA: New York Heart Association

$\geq 75$-year-oldpatients during a long-term follow-up period [22]. In our study, we found that one-year mortality was strongly associated with rescue $\mathrm{CRT}$ and AF, which were not age-related. CKD was not associated with mortality in the $\geq 75$ age group and was only associated with mortality in younger patients. The COMPANION trial reported that CRT reduced all-cause mortality only in patients with a defibrillator [2], whereas defibrillator use was not associated with survival in either the $<75$ - or $\geq 75$-year-old patients in our study. We also found that ivabradine use was predictive of deaths in older patients. We have no explanation for this finding, as it has not been reported before and may be hazard-related. In contrast, a recent study showed that ivabradine was well tolerated in patients $\geq 70$ years old with systolic HF [23].

There was no difference concerning complications after CRT implantation between age groups. Despite higher rates of comorbidities and advanced HF, age $\geq 75$ years was not associated with a higher complication rate. This result is consistent with those in most published data [9,
15]. Höke et al. reported only a trend towards a higher incidence of pneumothorax and pocket hematoma in $\geq 75$ year-old patients [22]. Nevertheless, the risk of adverse events is the most frequently reported explanation for the CRT age limit observed in European centers [24]. As reported recently, we found that CRT defibrillator use was more strongly associated with complications than was CRT pacemaker use, regardless of age [25].

Thus, our results suggest that CRT is essential for older adults. It is difficult to "optimize" treatment for these patients because CKD and hypotension limit the medical therapies, disabilities limit cardiac rehabilitation and other age-related features defining frailty in elderly individuals limit therapies. Patients over 75 years of age with advanced HF and a high NYHA class, even with AF, should be considered for CRT. Age should not be a limitation itself; rather, individual risk has to be evaluated in combination with other comorbidities to select CRT candidates and whether this device is associated with defibrillator use. 

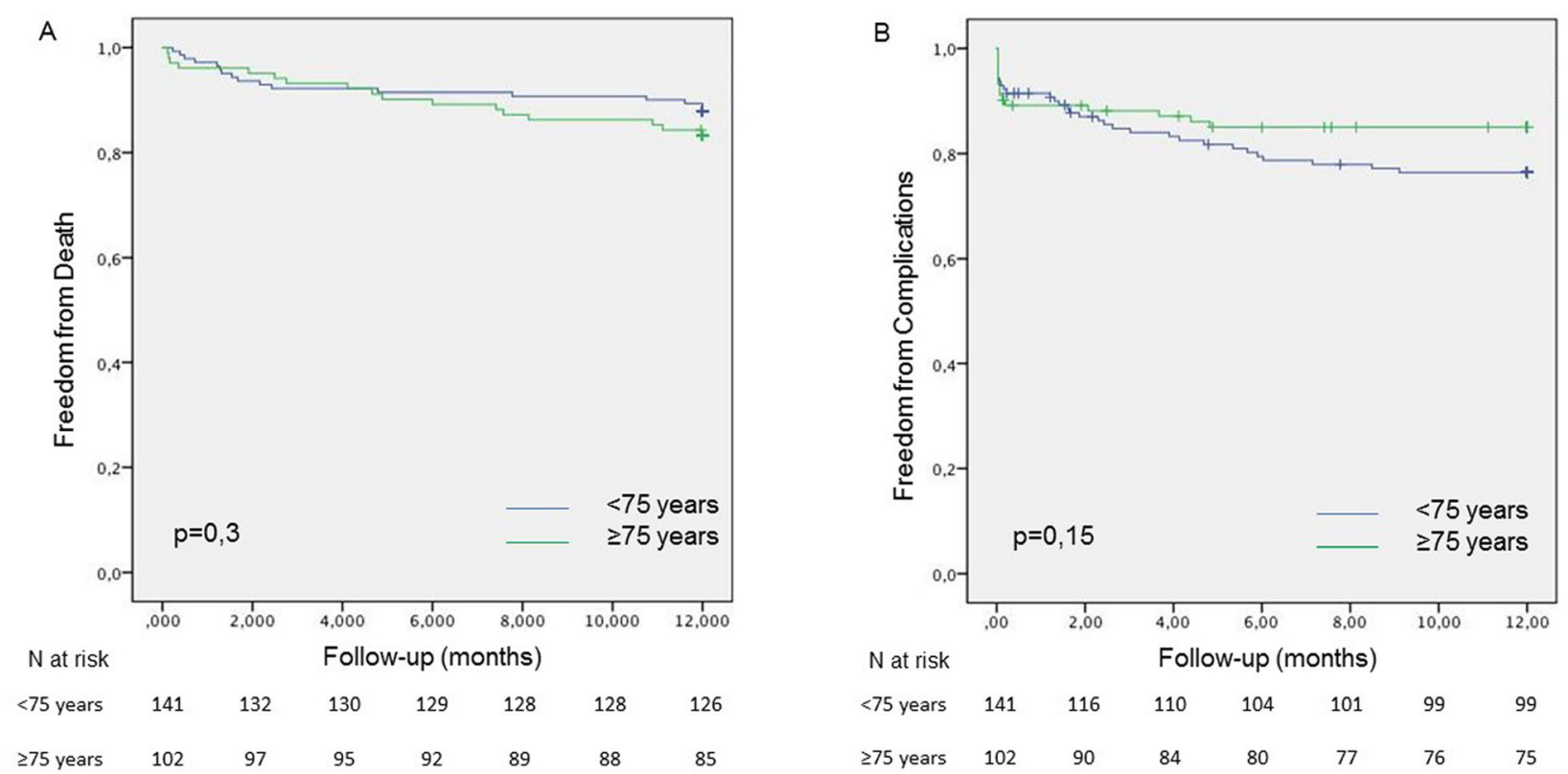

Fig. 1 Kaplan-Meier curves for one-year mortality and complications in the $\geq 75$ - and < 75-year-old groups. Panel a: Overall survival, Panel $\mathbf{b}$ Complications. The $\geq 75$-year-old group corresponds to green, and the $<75$-year-old group corresponds to blue. Comparisons were made with the log-rank test

\section{Limitations}

Some limitations of our study should be addressed. This retrospective study with a small sample size may be underpowered and is subject to selection bias. Except in cases of rescue CRT, we can assume that the frailest elderly patients did not undergo implantation, which could lead to an overestimate of the CRT benefit among the $\geq 75$-year-old group. We did not report other data about functional status like the six-minute walking distance. Other studies reported similar improvements in the sixminute walking distance after CRT in older patients compared to younger counterparts $[8,9]$. Interestingly, the six-minute walking distance was found predictive of mortality in elderly patients undergoing cardiac rehabilitation after coronary bypass grafting, whereas LVEF was not [26]. Causes of death were not adjudicated and therefore were not analyzed. Last, we did not retrieve cognitive status, quality of life scores and end-of-life experiences, but these outcomes are important, especially for older patients [6]. Additional studies should be designed to address these issues, and test other potential predictors of clinical outcomes between younger and older patients with CRT.

\section{Conclusion}

Our study showed that very symptomatic older adults are likely to respond to CRT and that AF was not associated with worse outcomes. We also highlighted the safety and efficiency of CRT regardless of patient age.

\section{Abbreviations}

AF: Atrial fibrillation; CKD: Chronic kidney disease; CRT: Cardiac resynchronization therapy; HF: Heart failure; LBBB: Left-bundle branch block; LVEF: Left ventricular ejection fraction; NYHA: New York Heart Association

\section{Acknowledgements}

Not applicable

\section{Authors' contributions}

$L C R, A L C, P O, M C, A P, D L$, and PM conceived and designed the research. $L C R, A L C, P O, M C, A P$, and $D L$ collected and analyzed data. $P O, L C R$, and $A L C$ performed the statistical analysis. LCR, ALC, and PM wrote the manuscript. All authors made critical revisions to the manuscript and approved the final version. LCR and ALC contributed equally.

\section{Funding}

This study received no funding.

\section{Availability of data and materials}

The datasets used and/or analyzed during the current study are available from the corresponding author upon reasonable request.

\section{Ethics approval and consent to participate}

This retrospective study based on previously collected data was complied in accordance with the Declaration of Helsinki and French ethics guidelines. This study was approved by the regional ethics committee and the French committee of informatics and civil liberties (CNIL, conformity agreement $\mathrm{n}^{\circ} 2204611$ ). All patients received a non-opposition letter, as requested by French authorities for retrospective studies.

\section{Consent for publication}

Not applicable

\section{Competing interests}

The authors declare that they have no competing interests.

\section{Author details}

${ }^{1}$ Normandie University, UNICAEN, CHU de Caen Normandie, Service de Cardiologie, EA4650 (Signalisation, électrophysiologie et imagerie des lésions 
d'ischémie-reperfusion myocardique), 14000 Caen, France. ${ }^{2}$ Normandie University, UNICAEN, CHU de Caen Normandie, Service de Cardiologie, 14000 Caen, France.

Received: 26 June 2019 Accepted: 7 November 2019

Published online: 21 November 2019

\section{References}

1. Abraham WT, Fisher WG, Smith AL, Delurgio DB, Leon AR, Loh E, et al. Cardiac resynchronization in chronic heart failure. N Engl J Med. 2002; 346:1845-53.

2. Bristow MR, Saxon LA, Boehmer J, Krueger S, Kass DA, De Marco T, et al. Cardiac-resynchronization therapy with or without an implantable defibrillator in advanced chronic heart failure. N Engl J Med. 2004;350: 2140-50.

3. Cleland JGF, Daubert J-C, Erdmann E, Freemantle N, Gras D, Kappenberger $L$, et al. The effect of cardiac resynchronization on morbidity and mortality in heart failure. N Engl J Med. 2005;352:1539-49.

4. Moss AJ, Hall WJ, Cannom DS, Klein H, Brown MW, Daubert JP, et al. Cardiac-resynchronization therapy for the prevention of heart-failure events. N Engl J Med. 2009;361:1329-38.

5. Ponikowski P, Voors AA, Anker SD, Bueno H, Cleland JGF, Coats AJS, et al. 2016 ESC guidelines for the diagnosis and treatment of acute and chronic heart failure: the task force for the diagnosis and treatment of acute and chronic heart failure of the European Society of Cardiology (ESC)developed with the special contribution of the heart failure association (HFA) of the ESC. Eur Heart J. 2016;37:2129-200.

6. Kramer DB, Reynolds MR, Mitchell SL. Resynchronization: considering device-based cardiac therapy in older adults. J Am Geriatr Soc. 2013;61: 615-21.

7. Dickstein K, Bogale N, Priori S, Auricchio A, Cleland JG, Gitt A, et al. The European cardiac resynchronization therapy survey. Eur Heart J. 2009;30: 2450-60.

8. Delnoy PPHM, Ottervanger JP, Luttikhuis HO, Elvan A, Misier ARR, Beukema WP, et al. Clinical response of cardiac resynchronization therapy in the elderly. Am Heart J. 2008;155:746-51.

9. Foley PWX, Chalil S, Khadjooi K, Smith REA, Frenneaux MP, Leyva F. Longterm effects of cardiac resynchronization therapy in octogenarians: a comparative study with a younger population. Europace. 2008;10:1302-7.

10. Killu AM, Wu J-H, Friedman PA, Shen W-K, Webster TL, Brooke KL, et al. Outcomes of cardiac resynchronization therapy in the elderly. Pacing Clin Electrophysiol. 2013;36:664-72.

11. Verbrugge FH, Dupont M, De Vusser P, Rivero-Ayerza M, Van Herendael $H$, Vercammen J, et al. Response to cardiac resynchronization therapy in elderly patients ( $\geq 70$ years) and octogenarians. Eur J Heart Fail. 2013;15:203-10.

12. Rickard J, Cheng A, Spragg D, Green A, Leff B, Tang W, et al. Survival in octogenarians undergoing cardiac resynchronization therapy compared to the general population. Pacing Clin Electrophysiol. 2014;37:740-4.

13. von Elm E, Altman DG, Egger M, Pocock SJ, Gøtzsche PC, Vandenbroucke $J P$, et al. The strengthening the reporting of observational studies in epidemiology (STROBE) statement: guidelines for reporting observational studies. Ann Intern Med. 2007;147:573-7.

14. European Society of Cardiology (ESC), European Heart Rhythm Association (EHRA), Brignole M, Auricchio A, Baron-Esquivias G, Bordachar P, et al. 2013 ESC guidelines on cardiac pacing and cardiac resynchronization therapy: the task force on cardiac pacing and resynchronization therapy of the European Society of Cardiology (ESC). Developed in collaboration with the European Heart Rhythm Association (EHRA). Europace. 2013;15:1070-118.

15. Suleiman $M$, Goldenberg I, Haim M, Schliamser JE, Boulos $M$, Ilan $M$, et al. Clinical characteristics and outcomes of elderly patients treated with an implantable cardioverter-defibrillator or cardiac resynchronization therapy in a real-world setting: data from the Israeli ICD registry. Heart Rhythm. 2014; 11:435-41

16. Brambatti M, Guerra F, Matassini MV, Cipolletta L, Barbarossa A, Urbinati A et al. Cardiac resynchronization therapy improves ejection fraction and cardiac remodelling regardless of patients' age. Europace. 2013:15:704-10.

17. Achilli A, Turreni F, Gasparini M, Lunati M, Sassara M, Santini M, et al. Efficacy of cardiac resynchronization therapy in very old patients: the Insync/Insync ICD Italian registry. Europace. 2007;9:732-8.
18. Kron J, Aranda JM, Miles WM, Burkart TA, Woo GW, Saxonhouse SJ, et al Benefit of cardiac resynchronization in elderly patients: results from the multicenter InSync randomized clinical evaluation (MIRACLE) and multicenter InSync ICD randomized clinical evaluation (MIRACLE-ICD) trials. J Interv Card Electrophysiol. 2009;25:91-6.

19. Maass AH, Vernooy K, Wijers SC, van't Sant J, Cramer MJ, Meine M, et al. refining success of cardiac resynchronization therapy using a simple score predicting the amount of reverse ventricular remodelling: results from the markers and response to CRT (MARC) study. Europace. 2018;20:e1-10.

20. Providencia R, Marijon E, Barra S, Reitan C, Breitenstein A, Defaye P, et al. Usefulness of a clinical risk score to predict the response to cardiac resynchronization therapy. Int J Cardiol. 2018;260:82-7.

21. Healey JS, Hohnloser SH, Exner DV, Birnie DH, Parkash R, Connolly SJ, et al. Cardiac resynchronization therapy in patients with permanent atrial fibrillation: results from the resynchronization for ambulatory heart failure trial (RAFT). Circ Heart Fail. 2012;5:566-70.

22. Höke U, Putter H, Van Der Velde ET, Schalij MJ, Delgado V, Bax JJ, et al. Left ventricular reverse remodeling, device-related adverse events, and longterm outcome after cardiac resynchronization therapy in the elderly. Circ Cardiovasc Qual Outcomes. 2014;7:437-44.

23. Zachariah D, Stevens D, Sidorowicz G, Spooner C, Rowell N, Taylor J, et al. Quality of LIFE improvement in older patients with heart failure initiated on ivabradine: results from the UK multi-Centre LIVE:LIFE prospective cohort study. Int J Cardiol. 2017:249:313-8.

24. Chen J, Hocini M, Larsen TB, Proclemer A, Sciaraffia E, Blomström-Lundqvist $C$, et al. Clinical management of arrhythmias in elderly patients: results of the European heart rhythm association survey. Europace. 2015;17:314-7.

25. Barra S, Providência R, Boveda S, Duehmke R, Narayanan K, Chow AW, et al. Device complications with addition of defibrillation to cardiac resynchronisation therapy for primary prevention. Heart. 2018;104:1529-35.

26. Cacciatore F, Abete P, Mazzella F, Furgi G, Nicolino A, Longobardi G, et al. Six-minute walking test but not ejection fraction predicts mortality in elderly patients undergoing cardiac rehabilitation following coronary artery bypass grafting. Eur J Prev Cardiol. 2012;19:1401-9.

\section{Publisher's Note}

Springer Nature remains neutral with regard to jurisdictional claims in published maps and institutional affiliations.

Ready to submit your research? Choose BMC and benefit from:

- fast, convenient online submission

- thorough peer review by experienced researchers in your field

- rapid publication on acceptance

- support for research data, including large and complex data types

- gold Open Access which fosters wider collaboration and increased citations

- maximum visibility for your research: over $100 \mathrm{M}$ website views per year

At BMC, research is always in progress.

Learn more biomedcentral.com/submissions 